\title{
Cervical Meningocele
}

National Cancer Institute

\section{Source}

National Cancer Institute. Cervical Meningocele. NCI Thesaurus. Code C101210.

A cong enital abnormality in the cervical region of the spine in which the meninges

protrude through a defect in the spinal column. 